\title{
The Book of Ceremonies by Constantine VII Porphyrogennetos on the Organization of Competitions at the Hippodrome of Constantinople
}

\author{
Vadim V. KHAPAEV \\ Ph.D. (in History) \\ Associate Professor \\ History Department \\ Sevastopol State University \\ 33, Universitetskaya str., Sevastopol, 299053, Russia \\ +7 (978) 083-58-40 \\ khapaev007@mail.ru \\ Anton M. GLUSHICH \\ Undergraduate Student \\ The Higher School of Economics \\ 21/4, Staraya Basmannaya str., Moscow, 105066, Russia \\ +7 (978) 895-63-83 \\ barny.g@mail.ru
}

\begin{abstract}
The article focuses on the understudied topic both in Russian and Western historiography - the process of organizing sports competitions at the Hippodrome of Constantinople. The following aspects are analyzed: the drawing procedure and the participation of imperial officials in the draw ceremony, the classification of athletes, the order of chariot races, the rules of their supporter cheering (acclamations), the connections between these actions and the imperial cult, the seating layouts for various categories of spectators in the stands. The process of breeding and treating racehorses is examined. The unique Byzantine racing practice - the diversium - is described. Special attention is given to safety precautions during races. The largest competitions are characterized. The system of remuneration of professional athletes is studied. The main source of information on the organization of sports competitions in Byzantium is the treatise of Emperor Constantine VII Porphyrogennetos (945 - 959) "De Ceremoniis aulae Byzantinae" which contains an extensive on the Hippodrome of Constantinople. The complete translation of this voluminous
\end{abstract}


source into modern European language (English) was first published in Australia in 2012 and remains inaccessible to a wide range of researchers. It is concluded that in the Byzantine Empire of the Early Byzantine and Middle Byzantine periods professional competitive sports were a large and sophisticated industry. They were strictly controlled by the imperial power and formed an important part of the imperial cult. This system of organization of competitions is the first and unique example of close interaction between sports organizations and the state machine in the history of the world sports.

Keywords: sports; Constantinople; Hippodrome; organization of competitions.

\section{Introduction}

The organization of sports competitions in the Byzantine Empire was carried out both by the government (top-ranking officials and the emperor himself) that granted consent to competitions, set the dates for their running, and were involved in ceremonial aspects of the Byzantine sports life, as well as by non-governmental sports organizations - the parties of the hippodrome. The latter supervised the sports component of the competitions organization: the training of charioteers and the preparation of chariots, maintaining the tracks in good condition, and organizing entertainment in between the races. However, party members also actively participated in the imperial ceremonies held both at the Hippodrome and in the Great Imperial Palace.

In comparison with the ancient Roman period, the structure of the parties didn't undergo any significant changes. In Rome, there were four parties - the Blues (veneti), the Greens (prasinoi), the Whites (leukoi) and the Reds (rousioi). In the Byzantine period, their number and names remained the same.

But the role of two of the four parties in the state and society strengthened significantly. All circus parties were sports clubs called "factions". But the veneti and the prasinoi pushed aside the sports limits and turned into mass organizations - "demes", uniting all the supporters of a particular team according not only to their sports preferences, but also their political, ideological and even religious views. The rousioi and the leukoi didn't become demes, and found themselves in a subordinate position as sports clubs (factions) - the veneti patronized the leukoi, and the prasinoi supported the rousioi.

Based on the fact that two factions were in a subordinate position, a special classification of hippodrome charioteers was formed. They were divided into three classes: the factionaries (the best drivers of the prasinoi and the veneti, the sports elite); the mikropanites (the best drivers of the 
rousioi and the leukoi, candidates for the elite group); and the biga-drivers (backup drivers for more venerable charioteers in case they got injured or fell ill). The prasinoi and the veneti had only one factionary each; the rousioi and the leukoi - one mikropanite each. Biga-drivers were many in all four factions.

\section{Methods}

All the features and peculiarities of the hippodrome sports life are thoroughly examined in the treatise "De Ceremoniis Aulæ Byzantinæ" ("On the Ceremonies of the Byzantine Court"), otherwise called "The Book of Ceremonies" (Moffatt, Tall, 2012). This treatise must have been compiled under the supervision of and for the Emperor Constantine Porphyrogennetos, presumably, in 956 - 959. It includes the descriptions of every important ceremony in which the Emperor was routinely or occasionally involved during his reign. A large section is devoted to the Hippodrome of Constantinople and its role in the imperial ceremonials. This is a valuable source for studying the principals of organization of sports competitions, but it has hardly been used as such in the world historiography.

In the course of work with the source, various methods were used: both general scientific methods (analysis, synthesis, generalization, analogue approach) and a number of universal historical methods. The historical-genetic approach made it possible to explore the Byzantines' attitude to the organization of sports competitions and trace the changes in it over time. The historical-typological method enabled us to elicit the difference between the terms "demes" and "factions", which are traditionally considered to be synonyms, and to recreate the classification of the hippodrome charioteers.

\section{Literature Review}

In Russian and Soviet historiography, the studies were mainly focused on the political essence of the hippodrome parties. In Western historical science, more attention was paid to the internal structure of the parties (Guilland, 1965; Wolińska, 2011). Influenced by Cameron's work “Circus factions: Blues and Greens at Rome and Byzantium" (1976), Western historiography predominantly views hippodrome parties as organizations of radical sports fans, either than complex and legally functioning sports clubs with explicitly stated functions - both in sports and in public life (Crowther, 1996; Guttmann, 1981). Only a few scientists gave special attention to the sports life of the hippodrome, i.e. the classification of the hippodrome charioteers, festivals accompanied by major sports competitions, etc. (Schrodt, 1981).

Western researchers Guilland (1965), Schrodt (1981), and Wolińska (2011) based their conclusions in part on the analysis of the Book of Ceremonies. In Russian and Soviet historiography, this source 
has never been analyzed before in terms of the history of sports. Western scholars have also failed to fully exploit the potential of the Book of Ceremonies as a source on the history of sports. They have studied in detail the structure and organization of the parties, the constructional particulars of the hippodrome, the rules for conducting sports events. But the "behind-the-scenes" part of competitions has been practically neglected, namely the technical side of organizing the races, the draw ceremony, the examination procedure for chariots and horses, people involved in the events, including not only party members, but also high-ranking imperial officials, and even the emperor himself. Running races, which were held at the hippodrome much less often than horse races, but which were no less popular, have also been left on the sidelines.

The study of procedural details will allow us to fully understand the way the Byzantines perceived the sports and will help us fill in the gaps in the knowledge of this most interesting historical phenomenon.

\section{Results}

The following results were achieved in the course of the study.

1. It was the parties that performed the main organizational functions for sporting events at the hippodrome. This is evidenced by the large number of people of different occupations engaged by the parties in order to organize the games, as well as by the level of responsibility they bore providing technical equipment for the races and taking care of chariot drivers. The opposite point of view is held by Giatsis (2000), who believes that these duties lay with the civil service.

2. The degree to which the parties were involved in the imperial ceremonial and detailed regulation of competitions, described in the Book of Ceremonies, indicate that the attitude towards sports in Byzantium changed significantly, as compared to the ancient Roman period. In Rome, charioteers' competitions were just a spectacle organized by the rulers for the amusement of the crowd. In Byzantium, they became part of the cult of the emperor the one chosen by the God and the winner in all spheres of life. While in the early Byzantine period the ruler actively communicated with the audience during competitions, albeit with the help of his officials, in the Middle Byzantine period "free" communication was replaced by the announcement of slogans prescribed by the Book of Ceremonies.

3. For Byzantium it is typical for high-ranking officials to take an active part in the ceremonies of the hippodrome. For the Greco-Roman world, of which Byzantium became the successor, it is not common to appoint the highest officials of the empire (the domestic of the scholai and the domestic of the exkoubitoi) as leaders of the demes (demokrates), and to use 
government officials as race guards and clerks. Some official posts (the thessarios, for example) do not occur to us in any other ceremonies, which means that this official was in charge of races only. The one thing not clear yet is whether it was his permanent position or a temporary assignment.

4. Giatsis (2000) believes that the wages of drivers were paid by the state. But the evidence provided by Constantine Porphyrogennetos stating that if a driver is replaced, the substitute is paid by the senior driver or his faction (Moffatt, Tall, 2012), suggests that drivers were fully supported by the parties. The emperor and the court only paid win bonuses and other prizes.

5. The information about the emperor's support of a particular party is indirectly confirmed in the Book of Ceremonies - in acclamations and the procedure for greeting parties by the ruler.

6. Detailed stories in the Book of Ceremonies about running races at the hippodrome refute Giatsis's assumption (2007) that in Byzantium track-and-field sports were on the decline after the Olympic Games had been cancelled, and were completely replaced by equestrian races.

7. The unique phenomenon of races with the use of another driver's team of horses (diversium) and the procedures related to it is an example of the Byzantines' scrupulous attitude to identifying the strongest athlete.

\section{Discussion}

1. The organizational role of the Hippodrome parties. The party was a large organization which included people of various professions necessary for its proper functioning. Official and most influential party members undertook to keep chariots, horses, and other equipment in good condition and were partly involved in organizing the races. In order to do that they paid membership fees to the party's coffers. The list of expenses included drivers' wages, horse training, chariot maintenance, and entertainment during the breaks between the race rounds. Party members provided comfortable conditions for the audience: they pulled huge pieces of cloth over the stands for sun protection, sprinkled the arena with fresh sand with the addition of fragrant cedar shavings (Dil', 1908).

The support staff maintained by the parties included poets that wrote poems in honor of the emperor, composers that turned them into songs, bandmasters that conducted their performance, organists that accompanied the singers, sculptors and artists that painted the emperor, cursors that 
maintained order, guards that watched over the changing rooms where charioteers' belongings were kept, performers that entertained the audience between the races (dancers, mimes, acrobats, and jesters). But the primary concern of the parties, on which they spent the largest part of their funds, was the preparation and maintenance of drivers and their horses (Dil', 1908).

The parties' expenses were very high, and therefore, the party elite included wealthy powerful people. The demarchs from the city party core usually had a rank of not lower than the second imperial rank of the protospatharios. The leaders (demokrates) of the Peratic Demes were the domestic of the exkoubitoi (the head of the Imperial Guard) for the Greens (the prasinoi) and the domestic of the scholai (the army commander-in-chief, the second person in the state) for the Blues (the veneti) (Moffatt, Tall, 2012). Apparently, demarchs and demokrates performed ceremonial functions and lent administrative support, rather than covered the expenses.

The expenses of the parties were also high because the entrance to the Hippodrome for the residents of the capital was free. The stands facing the imperial box - the kathisma, were reserved for the parties. The most active fans sat in the first row, the second one was occupied by ordinary party members, and above them in the third row were demarchs and other important members of the demes. The rest of the supporters from that deme occupied the fourth row and the rest that followed (Giatsis, 2000). Standing places were also provided for the spectators who were not members of any of the parties. The Book of Ceremonies notes that after the military triumphs the emperor could let the prisoners, that were escorted through the Hippodrome with banners and war loot, watch horse races standing under the stands of the Greens (Moffatt, Tall, 2012).

The staff of the Hippodrome often watched the races from the athletes' changing rooms, the carceres, which every party had at the upper circles above the starting gates. The view upon the arena from the windows was magnificent. Some of the staff stood right beside the carceres. The guards and those responsible for the proper state of tracks settled along the separation barrier - the spina.

2. The drawing ceremony. The competition program was intended for two days. The first day was ceremonial; the second day was filled with contests. The first day usually opened with a ceremonial procession: the praepositus sacri cubicula (the emperor's first adviser, usually, a eunuch), two demarchs and the best charioteers of the senior demes (factionaries) visited the emperor in the Grand Palace, paid obeisance to him and asked for permission to conduct races. After that they went to the carceres where the drawing ceremony was held. Both the representatives of the parties and imperial officials took part in the draw. The drawing room, located in one of the rooms above the carceres, was called the Tribunal. 
The procedure was carried out as follows. The urn was placed in the center of the room. The factionaries put two balls of their faction inside the slots in front of the urn, as well as, apparently, the balls of the patronized "junior" factions - the veneti put the balls for the leukoi, the prasinoi for the rousioi. The silentiary (an official in charge of the order in the Grand Palace), being the representative of the praepositus, was seated in the middle; beside him there was a tribune; and in the third seat there was a footman, as the representative of the aktouarios, who, together with the praepositus, was responsible for the ceremonial aspects of competitions. The fourth was the imperial program-writer with two faction writers responsible for preparing race programs. Charioteers sat on either side, two on each side: the factionaries of the veneti and the prasinoi were seated beside the mikropanites of the leukoi and the rousioi, respectively.

Then the parties chose an overseer who would draw lots. He stated that teams of horses (which would often change from race to race) had been formed and approved, and asked if there were any objections. After that, the overseer threw four colored balls into the urn and spun it three times. After each spin, he took out one ball from the urn, which later did not participate in the drawing of lots. This way the order of charioteers on the most comfortable track (the leftmost, closest to the spina of the arena) in each race was determined. After the end of the draw, all the above-mentioned people would go up into the room where all the race equipment was stored and would discuss the order of chariots on the rest of the tracks in each race. This was decided without a draw. Then, they would go over the negotiated arrangements and report them to the writer for him to make up the competition program which would then be handed to the emperor and announced to the audience (Moffatt, Tall, 2012).

The above procedure was purely tokenistic, since there were usually four races, and each driver could start one race from the most advantageous track. The fairness of the draw was strictly controlled, and the parties would often have a heated debate over who and how should take up the remaining tracks. This was probably due to the individual characteristics of the horses used in each particular race. The representatives of the factions and the charioteers knew their strengths and weaknesses and tried to make the most of their position on the track.

The thessarios, an imperial official, finished the preparation. He would hang a velarium, a large white cloth, in front of the carceres. This was the sign for the citizens that the next day there would be horse races.

3. Checking on the readiness for the races. On the day of the races, the physical state of all the horses which were to take part in the competition was checked. It happened as follows. The thessarios took three full tagaria (a unit of measurement equal to $1.6 \mathrm{~kg}$ ) of barley and three 
bundles of hay and went to the stables of the veneti; then he returned and did the same thing at the stables of the prasinoi party. Then the charioteers (probably, the biga-drivers) called for the doors to the stables to be opened and fastened in one place. After that, the drivers, two party representatives and two overseers (probably, imperial officials that monitored the accuracy of the inspection) ordered the stablemen to take the horses one by one to the center of the stable, where the inspection took place.

By day, the overseers and biga-drivers went to the houses of elite charioteers - the factionaries and the mikropanites participating in the races. From there they all went to the room where the race equipment was kept. The demarch, a few party members and the rest of the team came there too. When they all got together, they started inspecting the barriers. In Byzantium, chariots started not from the gates, but from mechanical "boxes", conventionally called "traps". The officials and overseers examined the mechanisms for their simultaneous opening once again, and then the mechanic left them open and ready for the races. After that, the charioteers, overseers, and officials went down to the drawing hall (Moffatt, Tall, 2012). All these measures were taken to avoid the shady schemes that the parties could attempt to win the race.

4. The organization of cheering in the stands. The second day was devoted to the races which were usually divided into morning and afternoon races. During the break, the audience dined in the stands, and the emperor - in his palace. In the second half of the break, wrestling competitions, theatrical performances and other shows could be held on the stama - an area under the kathisma in the form of the Greek letter $\Pi$ where awards and performances were usually given between the race rounds. Then the competition continued (Giatsis, 2000). The stands supported their athletes fiercely chanting the word "Nike" ("Victory") addressed to the athlete of their team. But the fans also had ceremonial "duties': before and after the races, they had to shout slogans praising the God, the emperor and the athletes.

The texts of acclamations are given in the treatise "De Ceremoniis":

The overseer recites, "May he have victory from God"!

The Blues' supporters: “Our representative, Ouranios”! (The Greens: “Olympios”).

Then the Blues greeted the driver from their subordinate junior faction of the Whites, and the Greens did the same for the driver from the junior faction of the Reds. Next, in response to the overseer's words, the audience answered three times: "Victory to the Blue faction!" (The Greens: “to the Green!”). The overseer: "May our representative, Ouranios, have victory from God!" (The Greens: "Olympios"). After that, the mikropanites were welcomed the same way the factionaries had just been (Moffatt, Tall, 2012). 
The author of the Book of Ceremonies calls the best charioteers by name despite the fact that this instruction book is universal in character and should not mention specific names. This testifies to the enormous popularity of the best athletes of the empire, whose names must have become common nouns.

At the time when the Book of Ceremonies was being written, the veneti must have had more liking from the authorities. Several factors indicate to this effect. First, in the beginning the emperor had to make the sign of the cross over the Blues, and then the Greens. Second, the acclamations of the parties are different. The veneti chanted, "Members of the senate, rouse yourselves! Let us pray for the rulers!" The acclamations of the prasinoi were similar, but they were addressed not to the senate, but to the infantry and the tagmas - the city guard that took their orders from the city governor - the eparch (Moffatt, Tall, 2012).

5. The rules of horses and drivers replacement. The Book of Ceremonies details the procedure for replacing a horse if it gets ill on the race day. Since in each of the four race rounds different groups of horses were used, it was allowed to put one of the horses into a different team. If the horse, which took part in the first race, got injured, it was examined by two representatives from the opposing faction, two overseers and the race manager. If the injury was confirmed, the horse was replaced by one of the horses competing in the third race. It was important that the horse could then participate in its own race. The same procedure was in place with the horses from other races. Of course, this change was not good for the driver, as the horses got used to their roles in a team and learnt to cooperate with each other. But a professional athlete had to be able to drive an altered team no less skillfully (Moffatt, Tall, 2012).

Not only sick horses could be replaced. The drivers that felt unwell before the races were allowed to have substitutes. They were usually replaced by biga-drivers (the charioteers of a lower rank) from their party. The young athlete put on a special piece of clothing called the "replacement cloth" and spent the necessary number of races in it. These substitutions also meant that the payment would be redistributed between the athletes. If a factionary or a mikropanite got ill and had to take a substitute from his faction, he paid the replacement driver one silver coin (miliaresion) for each victory. If the substitute driver received prizes from the emperor, but did not take the first place, the question of reimbursement was decided by the replaced athlete. And if the substitute driver came last, he received nothing.

If the substitute demonstrated a high level of excellence and was generously rewarded by the emperor, the replaced athlete had no right to claim even a small part of his prize. If a driver was 
replaced at the end of the competition, when prizes were not that high, then the substitute driver was paid a fixed amount of 3 gold nomismas. If the substitute drove his own chariot, he got 3.5 nomismas (Moffatt, Tall, 2012).

6. The rules for holding a diversium. Among the main tasks for charioteers and the staff were keeping the chariots in good working order, as well as correctly selecting and combining the best horses into a team. In order to test individual skills of charioteers in isolation from the team of horses which they trained and competed with - there was a special type of competition - a diversium, i.e. races using another driver's team of horses. Before afternoon races, the emperor could give an order to exchange horses. Then the aktouarios took all the four charioteers to the finish line and made an exchange. Everything was exchanged: the horses, the service team, the people opening the barriers and the party overseers, i.e. each race was repeated in the exact opposite way. This was done so that the horses were prepared for the ride by the team that knew their temperament and habits. Only chariots were not exchanged, but their good condition and the team's honesty were assured.

The charioteers wore special distinctive clothes which showed that the Blues were the Greens, and the Reds were the Whites, and vice versa. The victorious driver went to the stands of his party to get his rewards, but if the victory was won thanks to the exceptional skills of the driver, then he was awarded at the stands of his rivals (Moffatt, Tall, 2012).

Sometimes, even a harder type of diversium was held. Demarchs, factionaries, mikropanites, bigadrivers and race managers went to the sphenda - the part of the arena opposite to the carceres. One of the four charioteers was chosen. He vowed to be unprejudiced and impartial. Then people from other factions took out 64 horses, 16 from each faction, and the driver-distributor combined teams of horses so that each team had a horse from each faction. This way, in front of the audience, 16 teams for four races were formed. Then, the three charioteers carried out the drawing of lots. As a result of the draw, the teams were chosen, and the driver who had formed the quadrigas took the remaining teams. Thus, it was in the interests of the driver-distributor to combine roughly equal quadrigas not to get outplayed (Moffatt, Tall, 2012).

Perhaps, Byzantium was the only state that paid so much attention to choosing the most skillful charioteer and designed especially difficult trials for the purpose.

7. The rules for running races.

The Hippodrome was the place where not only horse races, but also running competitions were held, although they were less often than chariot races. One of the days when running competitions were obligatory was the Festival of the Vow which took place on January $3^{\text {rd }}$ as part of the 
Christmas celebration. It included horse races as well, but running competitions came first. The parties did not prepare professional runners - their charioteers took some time to practice before the Festival and then participated in the running races.

The emperor gave permission to hold a running race the day before the festival, and the praepositus ordered the master of ceremonies to conduct the competition the following day. The preparation started in the evening - demarchs and the city governor (eparch) took up the duties of organization.

The following morning, officials met the emperor at the palace (as it was done before equestrian competitions) and went with him to the hippodrome. Then, at the stama, the drawing procedure was carried out, which determined the order of use of the best, leftmost track. Unlike the drawing ceremony for horse races, the running draw was conducted in public. For this reason, three or four days before the race, the praepositus had to instruct the person in charge of the drawing procedure at the stama to take the urn and practice in order to avoid misunderstandings at the draw in front of the spectators of the hippodrome.

Then the charioteers, who had turned into runners, went off to get ready, and the emperor gave his attendants coins-tokens to distribute to the poor as invitations to dinner with the emperor according to an ancient custom. There were four races, an award ceremony was held, and the emperor went to dinner.

Tight security measures were taken during running competitions since it was difficult to impede the movement of a racing chariot and it was easy to knock down a running athlete. Therefore, during the race, it was necessary to ensure that nothing would interfere with its course. Servants were to accompany the winners to secure their safety. The guards were also placed at the spina and near arena exits so that no one could run out onto the arena and get in the way of a runner. Two guards stood by the changing rooms to prevent anyone from entering or getting out of there; the members of the demes and those who were holding the runners' tunics were not allowed to the changing rooms until the end of the races. After the races, winners received awards commensurate with the prizes of charioteers and were invited to dinner with the emperor (Moffatt, Tall, 2012).

As part of another celebration (the Butchers' Festival), charioteers dismounted in the middle of the last race and finished it running and whipping each other as if continuing the ride - this marked the end of the sports season (Moffatt, Tall, 2012).

Although running competitions were held less frequently than chariot races, Michael IV the Paphlagonian (1034 - 1041) after his triumph over Bulgarian rebels organized both horse races and running competitions, while Nikephoros III Botaneiates (1078 - 1081) rewarded and appreciated runners as highly as charioteers (Guilland, 1965). Emperor Constantine VIII Porphyrogennetos (963 
- 1028) (the co-emperor of Basil II) participated in running races himself demanding that no one should yield to him (Psell, 1978).

\section{Conclusion}

The detailed description of equestrian and track-and-field sports in the imperial treatise "De Ceremoniis" indicates that in the Byzantine Empire sports formed not simple entertainment, but an important sphere of social life with clearly defined rules.

In the Middle Ages, the Byzantine Empire was the only state where sports represented a strictly standardized and clearly organized sphere of public life. The organization of festivities and their regulations were carefully controlled by imperial officials. The rules for the inspection of sports equipment were specified in detail, financial issues were regulated, the drawing process and other ceremonial procedures were strictly controlled, including the hanging of the velarium and reciting acclamations. The separation of duties in organizing competitions between the hippodrome parties and the state is an exceptional case in the history of sports of the Middle Ages.

The Byzantine Empire was the only state where so much attention was paid to determining the best charioteer. No other medieval state concentrated so much on the technical side of races and the related rituals.

\section{References}

Cameron, A. (1976). Circus factions: Blues and Greens at Rome and Byzantium. Clarendon Press.

Crowther, N. (1996). Sports Violence in the Roman and Byzantine Empire: A Modern Legacy. International Journal of the History of Sport (IJHS), 3, 445-458.

Dil', S. (1908). Justinian and Byzantine civilization in the 6th century. Saint Petersburg. (in Russian)

Giatsis, S.G. (2000). The organization of chariot racing in the great hippodrome of byzantine Constantinople. The International Journal of the History of Sport, 17(1), 36-68.

Giatsis, S.G. (2007). Sport in Byzantium. Erytheia, 28, 15-40.

Guilland, R. (1965). Études sur l’Hippodrome de Byzance, III- IV. Byzantinoslavica, 26, 1-33.

Guttmann, A. (1981). Sport Spectators from Antiquity to the Renaissance. Journal of Sport History, $8(2), 5-27$. 
Dictum Factum

Moffatt, A., Tall, M. (2012). Constantine Porphyrogennetos. The Book of Ceremonies, in 2 volumes. Canberra: Australian Association for Byzantine Studies Byzantina Australiensia, 2012.

Psell, M. (1978). Chronography. Translation, articles and commentaries by Ya. N. Lyubarskii. Moscow. (in Russian)

Schrodt, B. (1981). Sports in the Byzantine Empire. Journal of Sport History, 8(3), 40-59.

Wolińska, T. (2011). Constantinopolitan Charioteers and Their Supporters. Łódź: Studia Ceranea, $1,127-142$. 